\title{
A Developmental Study for Infant-Toddler Auditory \& Communicative Behavioral Checklist
}

\author{
Kyeongyeon Park', Jinsook Kim² \\ 'Department of Speech Pathology and Audiology, Graduate School, Hallym University, Chuncheon, Korea \\ ${ }^{2}$ Division of Speech Pathology and Audiology, Research Institute of Audiology and Speech Pathology, College of Natural Science, Hallym University, \\ Chuncheon, Korea
}

\section{영유아 청각 및 의사소통 행동 체크리스트 개발 연구}

박 경 연 $^{1}$ 김 진 숙 ${ }^{2}$

한림대학교 일반대학원 언어병리청각학과 ${ }^{1}$ 한림대학교 자연과학대학 언어청각학부, 청각언어연구소 ${ }^{2}$

\begin{abstract}
Purpose: The objective of this study is to develop an Infant-Toddler Auditory \& Communicative Behavioral Checklist (IT-ACBC). Methods: After analyzing several domestic related studies and 11 foreign checklists, 33 key-words were investigated. From the key words, the 72 preliminary items, 6 items for 12 month groups, were developed. 12 month groups were composed of 1-3, 4-5, 6-7, 8-9, $10-11,12-13,14-15,16-17,18-19,20-21,22-23,24-26$ months following general developmental checklist 'Korean developmental screening test for infant \& children' which has been utilized in clinical setting. This list will be used in order to compare auditory and communicative behavioral ability to the general developmental levels. 72 preliminary items were administered by 114 parents of infants aged from 1-26 months. One point was credited when an infant shows suitable response 'yes' for each item. After considering internal consistency reliability, frequency of response to each month group, and questions from respondents, 36 items, 3 items for 12 month groups, were finally extracted from the preliminary items. Results: The Cronbach's alpha coefficient of the 36 items was 0.973. Total scores of 36 items revealed statistical significance for developmental differences. The score of the checklist was significantly correlated with 'LittIEARS Auditory Questionnaire-Korean' score. The test-retest reliability was quite high with $r=0.940$. Conclusion: Conclusively, IT-ACBC was developed to evaluate auditory and communicative behavior in typically developing infants and toddlers and can be utilized for checking those behaviors briefly.
\end{abstract}

Key Words: Infant-toddler, Development of auditory and communicative behavior, Checklist, Screening test.

Received: March 7, 2016 / Revised: March 28, 2016 / Accepted: April 1, 2016

Correspondence: Jinsook Kim, Division of Speech Pathology and Audiology, College of Natural Science, Hallym University, 1 Hallimdaehak-gil, Chuncheon 24252, Korea

Tel: +82-33-248-2213 / Fax: +82-33-256-3420 / E-mail: jskim@hallym.ac.kr

\section{INTRODUCTION}

언어습득 이론은 학습을 통해 배우는 것이 아니라 선천적으 로 가지고 태어난다고 주장하는 생득주의, 일반적인 학습으로 언어 및 의사소통능력이 발달하여 언어습득이 후천적이라고 강조하는 행동주의, 중간 절충이론인 여러 요인의 상호 영향을 중시하는 상호작용주의이론이 있다(Behme \& Deacon, 2008). 상호작용주의이론 중 특히 수용적 측면의 요인을 분석하면 영 유아기의 언어발달을 위해서 상징적 체계의 의미표현인 인간의 말을 듣는 수용언어를 충분히 경험해야 하는 것으로 생각할 수
있다. 수용언어의 경험은 청각기관을 통해 이루어진다. 태아의 청각기관은 임신 8주에 인간의 형상을 나타내기 시작하여, 내 이의 코르티기관을 포함한 와우관이 태아기 20 주에 여러 감각 기관 중 가장 먼저 성인의 형태를 갖추고, 초기 기능도 가능하 여 말소리를 수용하는 능력도 생긴다(Sánchez Del Rey et al., 1995). 따라서 태아는 양수의 진동을 통해 소리를 직접 듣는 '골 도' 청력으로 총 재태기 40주 중 후반기 20주 동안은 주변 및 말소리를 듣는 것으로 생각되며 실질적으로 재태연령 25 29 주부터 청각 자극에 대하여 일관된 반응을 하기 시작한다. 이 런 태내의 청각 경험을 바탕으로 영유아는 태내에서 이미 초분 
절적인 정보를 습득하고 생후 1 6개월 시기에 초분절적인 정 보와 분절적인 정보에 대해 인지학습을 한다. 7 12개월의 영유 아는 학습을 통하여 이미 습득한 초분절적인 정보를 조직화하 고 의미 있는 분절적인 정보를 배우는 데 초점을 둔다. 영유아 의 경우 언어 및 말소리를 청각적으로 인지하기 위하여 인지기 억, 연관학습, 통계적 학습, 사회적 상호작용과 경험에 대한 동기 유발로 총 네 가지 메커니즘을 통하여 학습을 하고(Houston, 2008; Younger \& Cohen, 1986), 음운을 반복적으로 들으면서 기억능력이 활성화되어 모국어의 말소리에 민감하게 반응을 하 기 시작하며 사회적 상호작용과 경험으로 언어를 습득하게 된 다(Bloom \& Tinker, 2001).

출생 후 3 년 동안은 가장 먼저 시작된 청각언어발달 과정이 이후의 언어를 포함한 기본적인 행동 발달과 성장에 기반이 된 다. 인간의 성장발달과정에서 특정적 행동이 급격히 발달하는 시기는 정해져 있는데, 7 세 이전이 영유아의 전반적 발달에 결 정적 시기(critical period)이다. 그 중 청각언어발달에 중요한 결 정적 시기는 3세로 이 시기 내에 포함된다(Yee \& Oh, 2006). 인 지, 언어, 사회성, 자조 등 다양한 영역의 고른 발달이 중요하지 만, 특히 청각발달이 우선되어야 하는데, 그 이유는 청각발달이 제대로 이루어지지 않으면 언어발달에 치명적인 영향을 미치고, 의사소통 발달과 다른 발달 영역에 영향을 주기 때문이다(Tait et al., 2007). 이러한 청각인지 기능의 발달은 언어습득을 위한 언어자극의 경로가 되고 의사소통 능력의 발달에 기초가 된다 (Northern \& Downs, 2014). 따라서 영유아기의 청각 발달에 대 한 평가는 조기에 시행되어야 하고 의사소통 능력을 함께 평가 하여야 한다. 더욱이 우리나라의 2012년 영유아건강검진 결과 현황에 의하면 신체질환 소견 결과를 청각, 시각, 피부, 귀, 코, 눈, 생식기, 구강/목 등 총 17 개로 분류하여 이상소견 비율을 분석하였을 때 청각이 $1.70 \%$ 로 1 위를 차지하였고 귀는 $0.26 \%$ 로 4위를 차지하여 청각과 귀에 이상이 매우 두드러지는 것으 로 나타났다(National Health Insurance Service, 2012). 따라 서 영유아 시기의 청각과 관련된 체계적인 검진과 평가가 중요 한 것으로 생각된다.

선천성 난청이 있을 경우 청각장애의 조기 발견과 조기 재활 은 정상에 가까운 인지능력 및 사회성 발달에 효과가 있다. Yoshinaga-Itano et al.(1998)은 6개월 이전에 청각장애로 진단 된 그룹이 이후 진단된 그룹보다 전반적 발달영역에서 더 나은 발달을 보였다고 보고하는데, 이러한 결과는 난청 정도, 인지 력, 인종, 성별 등과는 무관하고 선천성 난청은 주로 열성유전 의 영향으로 발생하여 난청 이외에 다른 장애를 동반하는 경우 가 많지 않은 것과도 관련이 있다. 그러므로 청각 및 의사소통 행동의 장애가 있을 경우 재빨리 발견하고 각 아동의 필요에 따 른 맞춤형 재활을 시행하기 위하여 청각 및 의사소통 행동 과
정에 대한 체계적인 점검이 필요하다.

우리나라는 영유아 장애 조기진단의 중요성을 고려해 2007 년 11월부터 영유아 건강검진 국가사업이 시행되고 있다. 이 사 업에서 발달 선별 검사에 사용되는 도구는 부모가 직접 설문지 를 작성하는 형태의 표준화된 검사도구인 Korean Ages and Stage Questionnaires와 아동 관련 전문가에 의해 시행되어야 하는 Denver-II가 사용되었으나, 적절성과 시행방법에 무리가 있어 2014년 이후 보건복지부는 '한국형 영유아 발달선별검사 도구 개발 및 타당도 평가 연구'(Eun, 2012; Eun \& Jeong, 2013) 를 통하여 독자 개발한 '한국 영유아 발달선별검사 도구(Korean Developmental Screening Test for Infant \& Children, K-DST)' 를 영유아 국가건강검진에 적용하고 있다(Ministry of Health and Welfare, 2014). 이는 총 6개의 핵심적인 발달 영역, 대근육 운동, 소근육운동, 인지, 언어, 사회성, 자조 영역을 평가한다. 각 발달 영역당 월령구간별로 검사문항은 8 문항씩으로 구성되어 있다. 이 중 언어영역의 문항들은 옹알이, 말하기, 듣기 등 연령 에 기대되는 수준의 언어발달을 하고 있는지를 포괄적으로 평 가하도록 구성되어 있고 청각 및 의사소통 능력 수준을 단계별 로 평가하고 구체적인 발달 정도를 파악하기에 어려움이 있다.

그러나 다수의 영어권 국가에서는 영유아기와 아동기의 청 각 및 의사소통 행동을 독립적으로 평가하는 체크리스트가 개 발되어 사용되고 있다. 예를 들어, 미국의 'Your Baby's Hearing and Communicative Development Checklist' (National Institute on Deafness and Other Communication Disorders, 2010), 뉴질랜드의 ‘Can Your Baby Hear?' (Ministry of Health, 2008), 영국의 'Checklist for Parents' (Newborn Hearing Screening Wales, 2016), 캐나다의 'Baby's Communication Checklist' (The Hearing Foundation of Canada, 2016) 등이 있다. 청각 및 의사소통 행동은 여러 발달 영역에 기반이 되고 초기에 체 크리스트를 간편히 점검하여 영유아의 청각 및 의사소통 행동 수준을 평가하여 조기 재활로 매우 좋은 결과를 얻을 수 있어 특히 독립적인 평가가 필요한 부분이다. 따라서 국내에서도 이 러한 영어권의 체크리스트를 번역하여 사용하고자 하였으나, 문화 - 정서적, 언어, 발달단계의 차이 등으로 해외의 청각 및 의 사소통 행동 체크리스트를 그대로 번역하여 사용하지 못하고 있는 실정이다.

국내에서도 영유아 및 아동의 발달 검사에 관한 여러 연구가 이루어져 왔지만, 영유아 시기의 청각 및 의사소통 행동을 평 가하기에 부족함을 보이고 있다. 그 예로 '한국어판 영유아 언 어 및 의사소통 선별검사의 타당도 및 신뢰도의 연구(Pae et al., 2015)는 4 36개월 아동의 전반적인 언어능력을 확인하는 데 사용될 수 있으나 청각 영역을 포함하고 있지 않아 초기 의 사소통의 기초를 세우는 청각과 관련된 의사소통 행동을 검사 
하고 있지는 못한다. '영유아 발달 선별검사를 위한 체크리스트 개발 및 타당도 검정'의 연구(Ju et al., 2009)는 영유아의 개인 사회성, 미세운동, 적응발달, 언어발달, 운동발달 등 전반적 발 달을 평가하는 것을 목적으로 총 38 개의 문항을 제시하였으나 언어발달에 대한 항목은 전체 월령구간 중 10 개 남짓뿐이고 언 어발달 중심의 항목이다. '한국형 영유아 발달선별검사 도구 개 발 및 타당도 평가 연구’(Eun, 2012; Eun \& Jeong, 2013)의 내 용을 중심으로 개발된 K-DST는 대근육운동, 소근육운동, 인 지, 언어, 사회성, 자조 영역 발달 등을 4 71개월 대상으로 포괄 적으로 평가하고 있고, 언어발달 중심의 문항이며, 해당 월령구 간에만 적용할 수 있는 평가도구여서 영역별 발달단계의 수준을 파악하는 데 무리가 있다. 그 이외에 '영유아 청각행동 발달 검사 개발을 위한 기초연구'(Lee \& Jang, 2010)는 인공와우를 착용한 아동을 위한 '듣기수용' 능력을 평가하는 기초연구로 의미적 수 용능력만을 평가하는 제한점이 있고, 생후 48개월까지 포괄적 으로 검사하여 영유아기의 청각언어발달에 중요한 결정적 시기 에 초기 청각 및 의사소통 행동을 평가하기에 부족함이 있다.

따라서 본 연구는 여러 발달 영역에 기반이 되는 청각 및 의 사소통 행동을 초기에 쉽게 판단하고 국내 영유아의 청각 및 의사소통 행동 상황을 체계적인 발달단계에 비교하여 분석하 고 영유아의 초기 청능재활에 기초선과 재활 후 평가방법으로 간단히 사용할 수 있는 영유아의 청각 및 의사소통 행동 체크
리스트를 개발하고자 한다. 개발과정은 국내의 영유아의 청각 및 언어 인지 기능 발달의 차이를 확인하고 국내 영유아의 청 각 및 언어 인지 발달 기준을 근거로 한국의 문화와 정서에 맞 고 한국어를 모국어로 하는 한국 영유아에게 적합한 영유아 청각 및 의사소통 행동 체크리스트를 제작하기 위하여 키워드 중심으로 예비문항을 작성하였다. 이후 영유아의 발달단계에 따른 문항으로 작성하고 청각 및 의사소통 능력을 제대로 평가 할 수 있는지 확인하여 수정 과정에서 문항에 대한 신뢰도와 타당도를 검증한 후 분석하여 최종 청각 및 의사소통 행동 체 크리스트를 제작하고자 한다. 이러한 체크리스트는 국내 영유 아의 전반적인 발달 영역과 청각 및 의사소통 행동 발달과정을 비교 분석하여 국내 청각장애아의 발달 지체되는 영역과 시기 를 확인하고 이를 조기 청능재활에 적용하여 더욱 효율적인 조 기 청능재활을 구현하는 데 목적이 있다.

\section{MATERIALS AND METHODS}

국내 영유아를 위한 청각 및 의사소통 행동 체크리스트를 개 발하기 위하여 총 7단계의 개발 과정을 다음과 같이 진행하였 다. 최종 목적은 12 개의 월령 구간별 각 3 개씩 총 36 개의 체크 리스트 항목을 개발하는 것이지만, 해외 및 국내 체크리스트, 관련문헌 조사와 키워드 중심의 문항분류, 발달단계에 적합한

Table 1. Foreign and domestic references of hearing and communicative behavior related checklists

\begin{tabular}{|c|c|c|c|}
\hline & Checklists & Institute/nation & $\begin{array}{c}\text { Age } \\
\text { range }\end{array}$ \\
\hline & $\begin{array}{l}\text { Your Baby's Hearing And Communicative Development } \\
\text { Checklist }\end{array}$ & $\begin{array}{l}\text { National Institute on Deafness and Other Communication } \\
\text { Disorders (NIDCD, US) }\end{array}$ & $\sim 60 \mathrm{~m}$ \\
\hline 2 & Hearing Checklist_Can your baby hear? & Ministry of Health (New Zealand) & $\sim 10 \mathrm{~m}$ \\
\hline 3 & Checklist for Parents & Newborn Hearing Screening Wales (UK) & $\sim 12 \mathrm{~m}$ \\
\hline 4 & Your Baby's Hearing Checklist & Maryland Infant Hearing Program (US) & $\sim 24 \mathrm{~m}$ \\
\hline 5 & Hearing Checklist for Parents & Texas Health and Human Services Commission (US) & $\sim 36 \mathrm{~m}$ \\
\hline 6 & Stages in Hearing Development & $\begin{array}{l}\text { The West Virginia Department of Health and Human } \\
\text { Resources (US) }\end{array}$ & $\sim 24 \mathrm{~m}$ \\
\hline 7 & Your baby's Hearing Development Checklist & National Institute for Children's Health Quality (NICHQ) & $\sim 36 \mathrm{~m}$ \\
\hline 8 & Baby’s Communication Checklist & The Hearing Foundation of Canada (Canada) & $\sim 30 \mathrm{~m}$ \\
\hline 9 & Speech and Hearing Checklist & Texas Children’s Hospital (US) & $\sim 60 \mathrm{~m}$ \\
\hline 10 & Your Baby’s Hearing Development Checklist & $\begin{array}{l}\text { Pediatric Medical Group (MEDNAX national medical } \\
\text { group, US) }\end{array}$ & $\sim 24 \mathrm{~m}$ \\
\hline 11 & Speech \& Hearing Checklist & I Hear Foundation (India) & $\sim 36 \mathrm{~m}$ \\
\hline 12 & $\begin{array}{l}\text { Development \& Validation of a Checklist for Infant and } \\
\text { Child Developmental Screening }\end{array}$ & $\begin{array}{l}\text { Ju et al. (Journal of Korean Academy of Child Health } \\
\text { Nursing, 2009). }\end{array}$ & $\sim 18 \mathrm{~m}$ \\
\hline 13 & $\begin{array}{l}\text { A Study on the Development and Validation of Korean } \\
\text { Developmnet al Screening Test for Infants \& Children }\end{array}$ & $\begin{array}{l}\text { Eun \& Jeong (Korea Centers for Disease } \\
\text { Control and Prevention, 2012; 2013) }\end{array}$ & $4-71 \mathrm{~m}$ \\
\hline & $\begin{array}{l}\text { A Preliminary Study on the Developmnet of Auditory } \\
\text { Behavior Checklist for Infant-Toddler }\end{array}$ & Lee \& Jang (Korean Academy of Audiology, 2010). & $\sim 48 \mathrm{~m}$ \\
\hline & $\begin{array}{l}\text { The Validity and Reliability of the Korean Version of the } \\
\text { Developmental Snapshot }\end{array}$ & Pae et al. (Communication Sciences \& Disorders, 2015) & $4-36 \mathrm{~m}$ \\
\hline
\end{tabular}


월령구간별 총 72 개 예비 문항을 시안으로 제작하여 신뢰도 분 석 후 월령구간에 가장 적절한 문항들을 선택할 수 있도록 하 였다. 선택된 최종 문항은 신뢰도와 타당도 분석을 통해 문항의 적절성을 확인하였다.

\section{1단계: 해외 및 국내 체크리스트 수집}

본 연구에서는 Table 1에서 제시한 해외의 총 11개 도구(I Hear Foundation, 2015; Maryland Infant Hearing Program, 2016; Ministry of Health, 2008; National Institute for Children's Health Quality, 2012; National Institutes of Health Consensus Development Conference Statement, 1993; Newborn Hearing Screening Wales, 2016; Pediatrix Medical Group, 2016; Texas Children's Hospital, 2015; Texas Health and Human Services Commission, 2011; The Hearing Foundation of Canada, 2016; The West Newborn Hearing Screening, 2006)의 청각 발달과 관련된 문항 221개를 조사하고 해 석하였다. 또한 국내에서 제시된 4개의 자료(Eun, 2012; Ju et al., 2009; Lee \& Jang, 2010), 청각학 전공 저서(Kim et al., 2014)에서 제시하고 있는 '연령별 의사소통 발달 체크리스트' 등을 분석하여 청각발달 및 의사소통과 관련된 문항들을 분석 하여 청각 및 의사소통 행동 체크리스트에 사용하기 가능한 총 465개 문항을 정리하였다.

\section{2단계: 월령구간 설정}

영유아의 생활연령에 따라 영유아의 청각 및 의사소통 행동 체크리스트를 개발하고자 국내외 체크리스트의 월령구간을 조 사하였다. 참고한 체크리스트들은 각기 다른 검사 월령과 구간
으로 구성되었으며, 평균 검사 월령이 29.27개월로 대다수의 해 외 체크리스트들이 생후 2 3년 영유아의 청력 발달 과정을 평 가하고 있었다. 전반적인 발달과정과 비교할 수 있도록 선행 연 구의 월령구간을 우리나라 국가건강검진 중 영유아의 6개 영역, 대근육운동, 소근육운동, 인지, 언어, 사회성, 자조 영역 발달평 가로 2014년부터 사용되고 있는 K-DST를 참조하여 다음과 같 이 구성하였다. 1 3개월, 4 5개월, 6 7개월, 8 9개월, 10 11개 월, 12 13개월, 14 15개월, 16 17개월, 18 19개월, 20 21개월, 22 23개월, 24 26개월로 총 12 개의 월령구간이다. 영유아의 발 달 속도를 고려하여 대부분 2개월씩 단위로 구성되었으나 초기 3 개월과 만 2세의 월령구간은 1 3개월과 24 26개월로, 3개월 단위로 설정한 선행연구의 월령구간을 참조하였다. 영유아 시기 에 전반적인 발달과정과 청각 및 의사소통의 발달을 비교할 수 있도록 구성하기 위하여 이 월령구간을 채택하였다. 더욱이 $1 \sim 26$ 개월 사이에 청각 및 의사소통 능력이 매우 빠르게 발달 한다는 선행연구(Yee \& Oh, 2006)의 결과를 토대로 월령구간 은 평균 2 개월로 작성하여 월령에 따른 행동의 발달양상을 세 분하여 점검할 수 있도록 하였다.

\section{3단계: 키워드 작성에 따른 분류}

1 단계에서 정리한 465 개 문항을 청각 및 의사소통 행동 위계 에 따라 영유아의 행동 특성을 중심으로 키워드를 작성하고 참 고문헌의 문항들을 분류하여 영유아의 발달단계와 비교하였다. 청각 및 의사소통 행동 체크리스트는 주관적으로 주양육자에 게 관찰되는 청각 및 의사소통 행동 특성을 살펴보는 검사방법 이다. 즉, 아직 언어발달이 완성되지 않은 시기이므로 청각발달 에 따른 청각적 의사소통 행동 특성들을 포함하여 체크리스트

Table 2. 33 key-words for auditory and communicative behavior

$\begin{array}{ll}1 \text { Response to loud sounds } & 18 \text { Following directions } \\ 2 \text { Detection } & 19 \text { Knowing body parts } \\ 3 \text { Response to familiar voices } & 20 \text { Word recognition level } \\ 4 \text { Detecting the source of a sound } & 21 \text { Using words } \\ 5 \text { Response to his/her name } & 22 \text { Asking and understanding simple questions } \\ 6 \text { Laughter } & 23 \text { Hearing sounds in different locations } \\ 7 \text { Cooing } & 24 \text { Two word phrases } \\ 8 \text { Babbling } & 25 \text { Enjoy being read to } \\ 9 \text { Listening attentively } & 26 \text { Say his/her own name or someone's name } \\ 10 \text { Demanding } & 27 \text { Understanding and using phrases } \\ 11 \text { Response to music } & 28 \text { Enjoy sounds of radio and television } \\ 12 \text { Vocalization play } & 29 \text { Using negative words } \\ 13 \text { Getting attention } & 30 \text { Discriminating the size of objects } \\ 14 \text { Understanding "No" and "Bye-bye" } & 31 \text { Singing } \\ 15 \text { Response to familiar words } & 32 \text { Speech intelligibility } \\ 16 \text { Gesture } & 33 \text { Using many different consonant sounds } \\ 17 \text { Imitation } & \end{array}$


의 문항으로 구성할 수 있도록 키워드로 분류하였다. 선행 연구 를 분석하여 작성한 고빈도의 키워드를 26 개월까지의 청각 및 의사소통 행동을 고려하여 총 33개로 분류할 수 있었다. 33 개 의 키워드는 Table 2 와 같다.

또한, 한 키워드 안에서 청각 혹은 의사소통 행동에 다른 형 태를 보일 경우, 세부적으로 반응을 분류하였다. 예를 들어, 1 번 키워드 ‘큰 소리에 대한 반응'에는 놀라기, 빨기, 시선이동, 울음, 동작 멈춤의 5 가지 반응을 대표적으로 분류하여 세부적 반응 을 점검하고 대표적이고 일반적인 반응을 문항으로 작성하였다.

\section{4단계: 발달과정에 따른 월령구간별 문항 작성}

총 465 개 문항을 33 개의 키워드로 분류하고 설정한 월령구간 별로도 분류한 후, 국내 아동발달 단계에 따라 해당 월령구간 에 문항들을 우선 배치하였다. 영어권의 체크리스트들을 본 키 워드에 따라 분류하였을 때, 월령구간이 증가할수록 키워드 번 호도 발달 단계에 따라 증가하도록 구성하였고 예비 문항의 구 성도 이러한 발달위계에 근거하여 배치하였다.

국내외의 체크리스트들을 키워드에 따라 분류하고 한국 영유 아의 표준으로 적용하기 위하여 청각학, 언어병리학, 아동발달 학 전공서적 등(Kim, 2014; Kim et al., 2014; Lee et al., 2009) 을 참고하여 영유아 아동 발달의 청각 및 의사소통 행동 위계에 따라 월령구간별 문항을 작성하였다. 청각학과 언어병리학의 교 수 및 전문가 5 명이 전문지식을 활용하고 교차 분석하여 각 12 개 구간의 월령별 예비문항을 6 개씩 작성하였다.

최종적으로 문법적 철자의 오류 없이 각 월령구간에 맞는 청 각 및 의사소통 행동 체크리스트가 되도록 하고, 한국 정서에 이해하기 쉬운 언어를 사용해 문항이 작성되었는지 확인하기 위하여 영유아 부모들에게 시험 적용한 후 수정하고, 뜻이 간결 하게 작성되었는지 재차 수정 점검하여 월령구간별 예비문항 은 6개씩 총 72문항을 작성하였다.

\section{5단계: 자료 수집}

본 연구는 한림대학교 생명윤리위원회의 승인을 받았으며 (IRB 번호: HIRB-2015-008), 연구를 진행하기 전에 연구자가 대상자에게 연구내용 및 목적에 대한 충분한 설명을 제공하였 다. 최종 제작된 예비 72 문항을 선천적 장애나 청각 및 언어 장 애가 없다고 보고한 1 26개월 정상 영유아의 주양육자를 대상 으로 검사하였다. 각 월령구간별로 참여한 영유아의 주양육자 수는 1 3개월은 11명, 4 5개월은 14명, 6 7개월은 10명, 8 9개 월은 7명, 10 11개월은 9명, 12 13개월은 11명, 14 15개월은 9명, 16 17개월은 7명, 18 19개월은 8명, 20 21개월은 10명, 22 23개 월은 10명, 24 26개월은 8명으로, 총 114명이 참여하였다.

본 연구에서 완성된 영유아 청각 및 의사소통 행동 체크리스
트 예비 문항을 검증하기 위한 목적으로 온라인과 오프라인을 통해 자료를 수집하였다. 온라인의 경우 $\mathrm{Google} \mathrm{T}^{\mathrm{TM}}$ (Menlo Park, CA, USA)의 'Google Docs'를 이용해 웹 베이스로 설문형태를 제시하여 월령구간별로 응답자가 응답할 수 있도록 하였다. 온 라인을 통해 $77 \%$, 오프라인을 23\%의 자료를 수집하였다.

응답 형식은 영유아가 과거나 현재에 보였던 청각 및 의사소 통 행동은 '예’로 응답을 하고, 영유아에게 아직 나타나지 않은 행동은 '아니오'로 응답하도록 하였다. 각 문항에서 '예' 응답을 1점, '아니오' 응답은 0점으로 계산하였다. 영유아의 행동이 그 이전의 낮은 단계의 문항들에서 모두 '예’라는 응답으로 확신할 수 있는 수준인 기초선은 월령구간 내 6 문항 중 5 문항 이상이 '예' 응답일 경우로 정하여 월령이 더 낮은 문항은 응답하지 않 아도 모두 '예'로 분석하였다. 영유아의 행동이 그 이상의 단계 의 문항들에서 '아니오'라는 응답으로 확신할 수 있는 수준인 최고한계선은 월령구간 내 6 문항 중 5 문항 이상이 '아니오' 응 답인 경우로 설정하여 응답하지 않아도 모두 ‘아니오'로 분석하 였다. 또한, 각 문항에서 다른 청각 및 의사소통 행동을 조사하 기 위하여 기타란을 포함하여 본 시안에서 포함하지 못한 청각 및 의사소통 행동이 있는지 확인하였다.

\section{6단계: 신뢰도 분석 등을 통한 최종문항 선정}

36 개 최종 문항은 72 개 문항을 12 개의 월령구간별 신뢰도 분석 결과 항목 삭제 시 6개의 문항의 Cronbach's alpha 값이 증가하는 문항을 일차적으로 제거한 후 응답자가 답한 해당 월 령구간의 응답 중 행동이 자주 나타난 문항의 빈도를 순위화 하여 응답 빈도가 높은 문항으로 우선 선정하였다. 또한 해당 월령구간 외 문항에서 응답이 자주 나타난 문항을 제외하거나 월령구간 단계를 수정하였다. 그 예로 '누가 책을 읽어주면 좋 아한다.' '아기의 목소리는 정상이다.' 등이 있었다. 응답자들이 여러 번 질문하였던 문항을 고려하여 다음과 같이 최종 선정하 였다. 질문이 다수 있었던 문항의 예로 '소리가 나는 장난감을 좋아한다.' 문항에 대하여 '사용해보지 않아 모르겠다.가 있었 고, '동요를 따라 부른다.' 문항에 대하여 '어설프게 따라 한다.', '흥얼거린다.' 등의 질문으로 '예’, '아니오' 척도로 응답하기 어려 운 문항은 수정하거나 제거하였다. 따라서 최종 제작된 영유아 청각 및 의사소통 행동 체크리스트(Infant-Toddler Auditory $\&$ Communicative Behavioral Checklist, IT-ACBC)를 완성 하였다. 또한 최종 제작된 IT-ACBC의 전체문항의 내적 일관 성은 각 문항별 Cronbach's alpha 값 분석을 통해 실행하였다 (Appendix). 
7단계: 최종문항의 일원분산분석, 공인 타당도, 검사-재검사

\section{신뢰도 분석}

IT-ACBC의 월령구간간 발달 위계를 알아보기 위해 12 월령 구간의 총 점수에 대한 일원분산분석을 실시하여 월령구간에 따라 점수가 체계적으로 변하는지 확인하였다. 청력이 정상인 영유아와 인공와우나 보청기를 착용하는 청각장애 영유아의 듣기 발달 평가 도구인 LittlEARS Auditory Questionnaire Korean (LEAQ-K)와의 상관관계를 20명을 대상으로 분석하 여 공인타당도를 점검하였다(Sohn et al., 2015). LEAQ-K는 청력이 정상인 경우 1 24개월까지, 청각장애인 경우 인공와우 나 보청기를 착용하고 난 이후 2 년까지의 듣기 발달을 평가하도 록 구성되어, IT-ACBC와 비교할 때 월령구간별로 구성된 문항 은 아니지만 청각 및 의사소통 행동 내용 중 듣기 발달을 평가 하는 도구이며, 특히 평가기간이 유사하여 타당성을 입증하는 평가도구로 선정하였다. 검사시행의 일관성을 확인하기 위해 17 명을 대상으로 첫 검사 후 1 2주 검사-재검사 신뢰도를 측정하 였다.

Table 3. Internal consistency reliability in value of Chronbach's alpha for each of 12 month groups

\begin{tabular}{cc}
\hline Age group & Cronbach's alpha \\
\hline $1-3 \mathrm{~m}$ & 0.700 \\
$4-5 \mathrm{~m}$ & 0.731 \\
$6-7 \mathrm{~m}$ & 0.898 \\
$8-9 \mathrm{~m}$ & 0.948 \\
$10-11 \mathrm{~m}$ & 0.952 \\
$12-13 \mathrm{~m}$ & 0.940 \\
$14-15 \mathrm{~m}$ & 0.939 \\
$16-17 \mathrm{~m}$ & 0.940 \\
$18-19 \mathrm{~m}$ & 0.952 \\
$20-21 \mathrm{~m}$ & 0.958 \\
$22-23 \mathrm{~m}$ & 0.922 \\
$24-26 \mathrm{~m}$ & 0.934 \\
Total & 0.973 \\
\hline
\end{tabular}

\section{RESULTS}

총 6단계, 해외 및 국내 체크리스트 수집, 월령구간 설정, 키 워드 작성에 따른 분류, 발달 과정에 따른 월령구간별 문항 작 성, 자료 수집, 신뢰도 분석 등을 통한 최종문항 선정을 거쳐 $\mathrm{IT}-\mathrm{ACBC}$ 가 완성되었으며 7단계의 최종문항의 일원분산분석, 공인 타당도, 검사-재검사 신뢰도 분석을 실시하여 다음과 같 은 구체적인 결과를 얻었다. 각 월령구간 총점의 평균과 표준편 차는 1 3개월은 3.7점 $( \pm 1.7), 4 \sim 5$ 개월은 6.3점 $( \pm 1.2), 6$ 7개월 은 8.6점 $( \pm 2.0), 8$ 9개월은 11.7점 $( \pm 1.1), 10 ~ 11$ 개월은 14.7점 ( \pm 2.0), 12 13개월은 17.6점 $( \pm 2.2), 14 ~ 15$ 개월은 19.7점 $( \pm 2.4)$, 16 17개월은 23.5( \pm 2.7), 18 19개월은 25.6점 $( \pm$ 6.9), 20 21개 월은 31.7점( \pm 2.4), 22 23개월은 34.0점( \pm 1.7$), 24$ 26개월은 34.8 점 $( \pm 1.8)$ 이었다. IT-ACBC의 총 36문항의 Chronbach's alpha 값은 0.973 이고 월령구간별 내적신뢰도는 모두 0.700 이 상으로 높은 신뢰도를 보였다(Table 3).

IT-ACBC의 월령구간 간 발달위계를 알아보기 위해 12 월령 구간의 총 점수에 대한 일원분산분석을 실시한 결과, 월령구간 이 높아짐에 따라 총 점수가 향상하였으며, 유의수준 $p=0.000$ 으로 유의미한 차이가 나타났다(Figure 1). Bonferroni 사후분 석 결과, 모든 월령구간 간 유의미한 차이를 보이지 않았지만, 20 21개월과 24 26개월을 제외한 월령구간에서 두 단계 월령 구간 간 유의미한 차이를 보였다.

공인타당도를 검증하기 위해 20명을 대상으로 $\mathrm{LEAQ}-\mathrm{K}$ 를 검사한 결과와 상관분석을 시행하여, $r=0.808$ 으로 $p<0.001$ 유의수준에서 높은 상관관계를 보였다. 유사한 공인된 평가도구 인 LEAQ-K와 높은 상관성은 IT-ACBC가 영유아의 청각 및 의사소통 행동을 평가하기에 타당한 도구임을 입증하였다. 17 명을 대상으로 검사-재검사로 IT-ACBC의 신뢰도를 분석한 결과, $r=0.940$ 으로 $p<0.001$ 유의수준에서 매우 높은 수준 의 검사-재검사 신뢰도를 보였다.

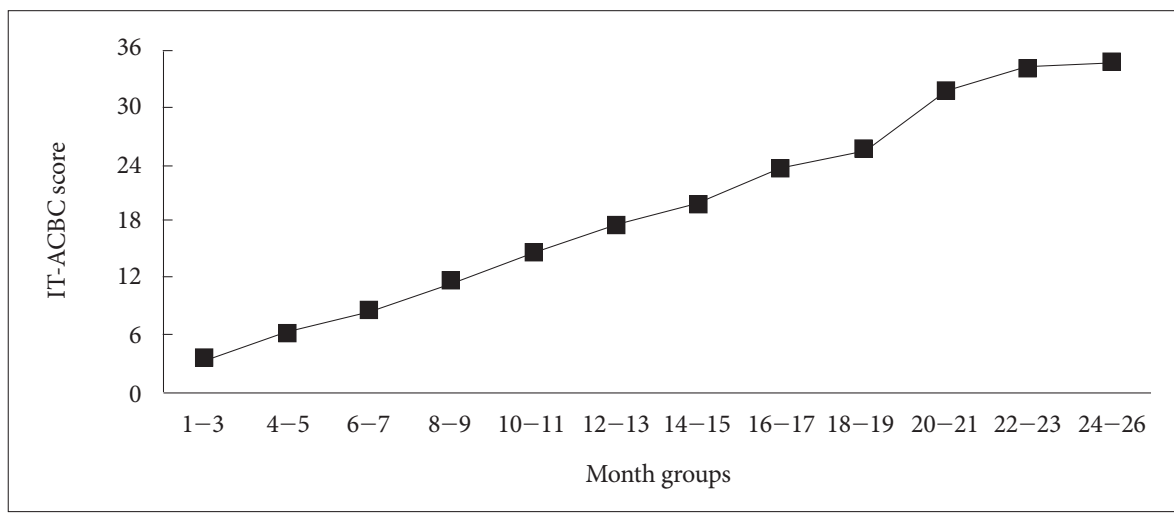

Figure 1. The scores of Infant and Toddler Auditory and Communicative Behavioral Checklist for each of 12 month groups. IT-ACBC: Infant-Toddler Auditory \& Communicative Behavioral Check- 


\section{DISCUSSIONS}

본 연구를 통하여 국내 영유아의 청각 및 의사소통 행동을 간편히 점검할 수 있는 36 문항의 IT-ACBC가 완성되었다. 또 한, IT-ACBC는 Chronbach's alpha 값, 월령구간별 내적신뢰도 검증, 타당도 및 검사-재검사 신뢰도 검증을 거쳐 한국 영유아 청각 및 의사소통 행동을 평가하기에 적절한 도구임을 확인하 였다.

해외의 체크리스트는 월령구간이 일정하지 않고 각 월령구간 내에 문항 수도 일정하게 구조화되지 않아 정상 영유아의 총점 을 표준화하는 데 어려움이 있다. 예를 들면, NIDCD의 'Your Baby's Hearing And Communicative Development Checklist' 는 월령구간이 0 3, 4 6, 7 12, 12 24, 24 36, 36 48, 48 60개 월이고 구간별 문항 수는 7, 8, 10, 8, 5, 6, 9문항이다. 그 외에도 The Hearing Foundation of Canada의 'Baby's Communication Checklist'는 월령구간이 $3,6,9,12,18,24,30$ 개월이고 구 간별 문항 수는 $3,3,4,4,4,4,3$ 문항이다. 청각 및 의사소통 행동의 결정적 시기(critical period)는 3세이며, 매우 빠른 속도 로 발달하여 월령을 세분화하여 행동특성을 점검할 필요가 있 다(Yee \& Oh, 2006). 그러나 해외 체크리스트는 월령구간이 일정하지 않을 뿐 아니라 7개월 이후 월령구간이 6개월이나 12 개월로 매우 넓게 구성하여 그 시기의 발달에 따른 행동특성을 평가하는 데 적절치 않다. 본 연구에서 개발된 IT-ACBC는 이러 한 단점을 보완하고자 월령구간을 평균 2개월로 선정하고 월령 구간별 문항도 3 개씩 일정하게 조정하여 차후 표준화가 가능하 도록 하였다. 또한, 영유아의 전반적인 6 개 영역, 대근육운동, 소 근육운동, 인지, 언어, 사회성, 자조 영역을 점검하는 $\mathrm{K}-\mathrm{DST}$ 와 같은 월령구간으로 구성하여 6개의 발달영역과 비교분석이 가 능하도록 하였다.

IT-ACBC는 내적 신뢰도가 0.973 으로 매우 높고 모든 문항 의 내적 신뢰도는 0.700 이상이었다. 이러한 높은 신뢰도는 문항 의 특성과 범위는 다르지만 개발된 다른 국내 선행연구의 결과 와 유사하다. Pae et al.(2015)의 '한국어판 영유아 언어 및 의사 소통 선별검사의 타당도 및 신뢰도'는 내적 신뢰도가 0.972 였 고, Lee \& Jang(2010)의 '영유아 청각행동 발달 검사 개발을 위 한 기초연구'는 내적 신뢰도가 0.821 이었다. 그러나 해외의 청각 및 의사소통 행동을 점검하는 체크리스트는 문항만 제시할 뿐 관련 연구나 신뢰도 분석을 찾을 수 없었다.

선행연구 중 생후 24 개월 이내에 청각장애를 발견하고 보장 구를 착용하기 시작한 어린 청각장애 아동의 듣기 발달을 평가 하는 LEAQ-K (Sohn et al., 2015)와 인공와우 아동의 청각발 달을 평가하는 영유아의 듣기 발달 체크리스트(Lee \& Jang, 2010)에서 성별 간 차이를 분석했을 때 통계적 유의성이 나타나
지 않았다. 따라서 본 연구는 더 어린 영유아를 대상으로 검사 하여 성별 간 분석을 시행하지 않았다. 그러나 차후 자료수집량 이 큰 경우 성별 간 차이가 없음을 확인하는 분석이 추가되어야 할 것으로 생각된다.

해당 문항이 묻는 청각 및 의사소통 행동에 다른 형태를 기 록하도록 구성된 기타 항목에 응답한 응답자는 전체의 시안 항 목당 평균 1.01 명으로 매우 적게 나타났다. 답변 내용 중 1 3개 월 영유아의 데이터 중 문항 '큰 소리가 나면 운다.'에 대해 '울지 는 않고 눈을 크게 뜨며 놀란다.라고 답한 내용은 같은 월령구 간에 문항 번호 1 과 응답 순위 1 번인 '갑작스러운 큰 소리에 놀 라거나 깬다.와 중복되어 수정이 요구되지는 않는 것으로 생각 되어 수정하지 않았다. 또한, 4 개월 영유아의 데이터 중 문항 '소리가 나는 곳을 찾으려는 행동(고개를 돌리는 등)을 한다.'에 대해 '백색 소음을 찾는다.' 등의 답변은 너무 전문적인 용어를 사용하여 수정 범위에서 제외하였다.

개발된 IT-ACBC는 국내 영유아의 전반적인 발달 영역과 청 각 및 의사소통 행동 발달과정을 비교 분석하여 국내 청각장 애아의 발달 지체되는 영역과 시기를 확인하고 이를 조기 청능 재활에 적용하여 더욱 효율적인 조기 청능재활을 구현하는 데 적절한 도구로 사용될 수 있다. 차후 IT-ACBC를 표준화하기 위하여 더 많은 주양육자를 대상으로 검사하여 각 월령구간별 정상 평균 및 표준편차를 제시할 수 있는 연구가 더 이루어지 길 바란다. 또한, K-DST와 연계한 연구도 우리나라 정상 영유 아의 청각 및 의사소통 행동 발달 정도를 영유아의 6 개의 발달 영역, 대근육운동, 소근육운동, 인지, 언어, 사회성, 자조 영역과 비교할 수 있는 연구로 이루어져 청각 및 의사소통 행동 발달 이 영유아의 전반적인 발달과 어떻게 연계되는지 확인할 수 있 는 연구가 이루어지길 바란다.

중심 단어 : 영유아-청각 및 의사소통 행동 발달·체크리스트. 선별검사.

\section{Acknowledgments}

본 연구는 2015년 대한민국 교육부와 한국연구재단의 중견연구 자 지원사업(인문사회:H00159)지원을 받아 수행된 연구임(NRF2015S1A5A2A01011541).

\section{REFERENCES}

Behme, C. \& Deacon, S. H. (2008). Language learning in infancy: Does the empirical evidence support a domain specific language acquisition device? Philosophical Psychology, 21(5), 641-672.

Bloom, L. \& Tinker, E. (2001). The intentionality model and language acquisition: Engagement, effort, and the essential tension in development. Monographs of the Society for Research in Child Development, 66(4), iviii, 1-91.

Eun, B. L. (2012). A study on the development and validation of Korean developmental screening test for infant and children (unpublished master's thesis). Korea University, Seoul. 
Eun, B. L. \& Jeong, H. J. (2013). A study on the development and validation of Korean developmnet al screening test for infants \& children. Korea Centers for Disease Control and Prevention (pp. 1-335). Cheongju: Korea Centers for Disease Control and Prevention.

Houston, D. (2008). Infant speech perception. In R. Seewald, \& A. M. Tharpe. Comprehensive Handbook of Pediatric Audiology (pp. 47-62). San Diego, CA: Plural Publishing.

I Hear Foundation. (2015). Speech and hearing checklist. Retrieved from http://www.salemschools. com/uploads/file/BSLE/bowsmanp/Speech and Hearing Checklist.doc.

Ju, H. O., Lee, N. Y., Park, I. S., Lee, S. O., \& Kim, S. H. (2009). Development \& validation of a checklist for infant and child developmental screening. Journal of Korean Academy of Child Health Nursing, 15(1), 34-41.

Kim, K., Kim, J., Kim, H., Bahng, J., Lee, K., Lee, J., et al. (2014). Introduction to Audiology. pp. 229-329. Seoul: Hakjisa.

Kim, Y. T. (2014). Diagnosis and Treatment of Language Disorders in Children. pp. 11-45. Seoul: Hakjisa.

Lee, M. S. \& Jang, H. S. (2010). A preliminary study on the development of auditory behavior checklist for infant-toddler. Audiology, 6(1), 60-75.

Lee, Y., Lee, J. H., Kim, O., Lee, M., \& Cho, S. (2009). Infant and Toddler Development. pp. 165-231. Seoul: Hakjisa.

Maryland Infant Hearing Program. (2016). Your baby's hearing checklist. Retrieved from http://phpa.dhmh.maryland.gov/genetics/docs/brochure_why_a_hearing_screening.pdf.

Ministry of Health and Welfare. (2014). Independent development of screening test for infant \& children: Provision comprehensive examination result sheet. Press release. Retrieved from http://www.mohw.go.kr/front_ new/al/sal0301vw.jsp?PAR_MENU_ID=04\&MENU_ID=0403\&page $=$ $118 \&$ CONT_SEQ=300932.

Ministry of Health. (2008). Can your baby hear? Retrieved from https://www. healthed.govt.nz/resource/newborn-hearing-screen-results-english-version.

National Health Insurance Service. (2012). Health examination result analysis. Retrieved from http://www.nhis.or.kr/bbs7/boards/B0077/6310.

National Institute for Children's Health Quality. (2012). Newborn hearing screening tools for parents. Retrieved from http://newbornhearing. nichq.org/resources/newborn\%20hearing\%20screening\%20tools $\% 20$ for\%20parents.

National Institute on Deafness and Other Communication Disorders. (2010). Your baby's hearing and communicative development checklist. Retrieved from https://www.nidcd.nih.gov/health/your-babys-hearingand-communicative-development-checklist.

National Institutes of Health Consensus Development Conference State- ment. (1993). Early identification of hearing impairment in infants and young children. Retrieved from http://consensus.nih.gov/1993/1993He aringInfantsChildren092html.htm.

Newborn Hearing Screening Wales. (2016). Checklist for parents. Retrieved from http://www.wales.nhs.uk/sitesplus/980/page/55652.

Northern, J. L. \& Downs, M. P. (2014). Hearing in Children. 6th Ed., pp. 127155. San Diego, CA: Plural Publishing.

Pae, S., Yoon, H., Seol, A., \& Gilkerson, J. (2015). The validity and reliability of the Korean version of the developmental snapshot. Communication Sciences and Disorders, 20(3), 355-363.

Pediatrix Medical Group. (2016). Your baby's hearing development checklist. Retrieved from http://www.pediatrix.com/body_hs.cfm?id=4425.

Sánchez Del Rey, A., Sánchez Fernández, J. M., Martínez Ibarguen, A., \& Santaolalla Montoya, F. (1995). Morphologic and morphometric study of human spiral ganglion development. Acta Oto-Laryngologica, 115(2), 211-217.

Sohn, M., Kim, J., \& Park, H. (2015). Auditory development assessment with LittlEARS auditory questionnaire in infants and toddlers with and without hearing loss. Audiology, 11(1), 45-62.

Tait, M. E., Nikolopoulos, T. P., \& Lutman, M. E. (2007). Age at implantation and development of vocal and auditory preverbal skills in implanted deaf children. International Journal of Pediatric Otorhinolaryngology, 71(4), 603-610.

Texas Children's Hospital. (2015). Speech and hearing checklist. Retrieved from http://www.texaschildrens.org/departments/hearing-center-audiology/speech-and-hearing-checklist.

Texas Health and Human Services Commission. (2011). Hearing checklist. Retrieved from http://hhsc.pinnaclecart.com/texas-health-steps/hearing-checklist-fact-sheet-eng-rev-03/12/.

The Hearing Foundation of Canada. (2016). Baby's communication checklist. Retrieved from http://www.hearingfoundation.ca/babys-communication-checklist/.

Newborn Hearing Screening. (2015). Stages in hearing development. Retrieved from http://www.wvdhhr.org/nhs/nhs-checklist.asp.

Yee, Y. H. \& Oh, M. Y. (2006). A comparative study between fathers and mothers on the parenting efficacy, knowledge of infant-care and sensitivity. Korean Journal of Human Ecology, 9(3), 47-62.

Yoshinaga-Itano, C., Sedey, A. L., Coulter, D. K., \& Mehl, A. L. (1998). Language of early- and later-identified children with hearing loss. Pediatrics, 102(5), 1161-1171.

Younger, B. A. \& Cohen, L. B. (1986). Developmental change in infants' perception of correlations among attributes. Child Development, 57(3), 803-815. 


\section{APPENDIX}

Infant-toddler auditory and communicative behavioral checklist

\begin{tabular}{|c|c|}
\hline Section & Contents \\
\hline \multirow[t]{3}{*}{$1-3 \mathrm{~m}$} & 갑작스러운 큰소리에 놀라거나 깬다. \\
\hline & 큰소리에 젖이나 우유병을 빠는 동작을 멈춘다. \\
\hline & 엄마 목소리(친숙한 목소리)를 듣고 울다가 조용해지는 등의 반응을 한다. \\
\hline \multirow[t]{3}{*}{$4-5 m$} & 소리가 나는 곳을 찾으려는 행동(고개를 돌리는 등)을 한다. \\
\hline & 이상한 소리(자음이나 모음으로 표현할 수 없는)를 내며 놀기 시작한다. \\
\hline & 반복적인 모음 소리(/아 /, /오 /)를 내기 시작한다. \\
\hline \multirow[t]{3}{*}{$6-7 \mathrm{~m}$} & 자기 이름에 반응하기 시작한다. \\
\hline & 다양한 소리(“껄껄”, “끼끼”, “걸걸”, 비명소리, ‘흐-읍’ 하며 들이마시는 소리 등)를 낼 수 있다. \\
\hline & 음악 소리를 좋아하고, 반응하기 시작한다. \\
\hline \multirow[t]{3}{*}{$8-9 m$} & 자기 이름에 작은 소리로 불러도 확실히 반응한다. \\
\hline & '까꿍’이나 ‘짝짝꿍’ 놀이 등을 따라하고 즐긴다. \\
\hline & 익숙한 물건의 이름(혹은 단어; 컵, 신발, 우유, 까까 등)을 안다. \\
\hline \multirow[t]{3}{*}{$10-11 \mathrm{~m}$} & 말소리와 같은 옹알이로 의사 표현을 하고 대화하듯 응답할 수 있다. \\
\hline & 간단한 말소리를 따라 내거나 흉내낼 수 있다. \\
\hline & 지시어(“가져와", "이리 와”, “더 줄까?” 등)의 의미를 알고 행동한다. \\
\hline \multirow[t]{3}{*}{$12-13 \mathrm{~m}$} & 어른들이 사용하는 어구(“이거 지지”, “아빠, 빠이빠이” 등)의 억양을 흉내낼 수 있다. \\
\hline & 지시어(“가져와”, "이리 와”, “더 줄까?” 등)뿐만 아니라, “너 신발 어디 있어?"와 같은 간단한 질문도 이해한다. \\
\hline & ‘엄마', ‘아빠’’ 이외에 적어도 한 단어 이상을 알고 사용한다. \\
\hline \multirow[t]{3}{*}{$14-15 \mathrm{~m}$} & 책 속의 그림을 가리키는 말('멍멍'-강아지, ‘빵빵’-차, '음메’-소 등)을 하면 해당 그림을 가리킬 수 있다. \\
\hline & ‘엄마’, ‘아빠’ 이외에 두, 세 개 정도의 단어를 알고 사용한다. \\
\hline & 간단한 질문을 이해하고 한 단어(“응”, “아니” 등)나 몸동작으로 답한다. \\
\hline \multirow[t]{3}{*}{$16-17 m$} & 간단한 심부름(기저귀, 신발, 컵 등을 가져오기)을 한다. \\
\hline & 10 20개의 단어를 알고 말한다. \\
\hline & 매일 새로운 단어를 배우고 사용한다. \\
\hline \multirow[t]{3}{*}{$18-19 m$} & 20개 이상의 단어를 알고 사용한다. \\
\hline & "나", "이거", "저거"와 같은 대명사를 사용할 줄 안다. \\
\hline & “배고파?”, “쉬 마려워?”와 같은 단순한 예-아니오 식의 질문을 이해한다. \\
\hline \multirow[t]{3}{*}{$20-21 \mathrm{~m}$} & “이게 뭐야?"와 같은 간단한 질문에 답한다. \\
\hline & 말로 하는 간단한 지시사항에 따라 행동한다. \\
\hline & 집에서 사용하는 다양한 일상적 어휘를 사용한다. \\
\hline \multirow[t]{3}{*}{$22-23 \mathrm{~m}$} & 단어의 끝 억양을 높여 질문의 형태로 묻는다. \\
\hline & 세 단어 이상을 사용하여 문장을 말한다(“아가 코 자”, “나 우유 싫어” 등). \\
\hline & “컵 안에”, “책상 밑에”, “의자 위에” 등의 부사구를 이해한다. \\
\hline \multirow[t]{3}{*}{$24-26 m$} & 사물의 크기를 구분한다(큰/작은 공). \\
\hline & 배설 욕구를 말이나 행동으로 표현한다. \\
\hline & "어디?"나 "언제?"와 같은 질문에 답한다. \\
\hline
\end{tabular}

